\title{
STATEMENT OF THE COMMITTEE OF HUMAN NUTRITION SCIENCE OF THE POLISH ACADEMY OF SCIENCES ON THE USE OF DIETARY SUPPLEMENTS CONTAINING VITAMINS AND MINERALS BY ADULTS*
}

\author{
Agata Wawrzyniak ${ }^{* 1}$, Katarzyna Przybytowicz ${ }^{* 2}$, Lidia Wadolowska ${ }^{* 2}$, \\ Jadwiga Charzewska ${ }^{* 3}$, Danuta Górecka ${ }^{* 4}$, Ewa Lange ${ }^{* 5}$ and other Members of the Committee \\ of Human Nutrition Science of the Polish Academy of Sciences ${ }^{6}$
}
${ }^{*}$ Committee of Human Nutrition Science, Department of Medical Sciences, Polish Academy of Sciences ${ }^{1}$ Department of Human Nutrition, Warsaw University of Life Sciences ${ }^{2}$ Department of Human Nutrition, University of Warmia and Mazury in Olsztyn ${ }^{3}$ National Institute of Public Health - National Institute of Hygiene in Warsaw ${ }^{4}$ Department of Gastronomic Technology and Functional Food, University of Life Sciences in Poznań ${ }^{5}$ Department of Dietetics, Warsaw University of Life Sciences

\begin{abstract}
${ }^{6}$ Stanisław Berger, Jerzy Bertrandt, Barbara Bobrowska-Korczak, Maria Borawska, Monika Bronkowska, Ewa Cieślik, Jolanta Czarnocińska, Magdalena Człapka-Matyasik, Anna Dtugosz, Matgorzata Drywien,, Mariola Friedrich, Ewa Gayny, Joanna Gromadzka-Ostrowska, Anna Gronowska-Senger,

Jadwiga Hamułka, Marzena Jeżewska-Zychowicz, Anna Kołtajtis-Dołowy, Zbigniew Krejpcio,

Teresa Leszczyńska, Renata Markiewicz-Żukowska, Zbigniew Marzec, Hanna Mojska, Regina Olędzka, Juliusz Przystawski, Joanna Sadowska, Matgorzata Schlegel-Zawadzka, Jerzy Socha, Katarzyna Socha, Piotr Socha, Iwona Traczyk, Jarostaw Walkowiak, Halina Weker, Marta Widz, Aneta Wojdyło, Matgorzata Woźniewicz, Katarzyna Zabłocka-Stowińska
\end{abstract}

\begin{abstract}
The use of dietary supplements (supplementation) is the individual enrichment of the diet with ingredients naturally occurring in food. As a rule, dietary supplements should be used periodically. In nutritional practice, there are many indications for dietary supplementation, but the decision to take dietary supplements should be made by consumers wisely and only in justified situations, when there is a risk that the usual diet does not provide vitamins and minerals in an amount adequate to meet dietary recommendations. However, we should remember about the real dangers of taking too large doses of vitamins and minerals. Many people using dietary supplements, especially several types at the same time, may experience undesirable side effects and deterioration of health, and in addition, people taking medicines may seriously disrupt or weaken the effect of the drug, or even lack the therapeutic effect of the drug. The document presents 10 steps and rules for the use of dietary supplements available on the market, which are addressed to the general population.
\end{abstract}

Key words: diet, minerals, vitamins, supplements, shortages, nutrition, food, adults

\section{STRESZCZENIE}

Stosowanie suplementów diety (suplementacja) to indywidualne uzupełnianie diety w składniki naturalnie występujące $\mathrm{w}$ żywności. $Z$ założenia suplementy diety powinny być przyjmowane okresowo. W praktyce żywieniowej istnieje wiele wskazań do suplementacji, ale decyzja o przyjmowaniu suplementów diety powinna być podejmowana przez konsumentów z rozsądkiem i tylko w uzasadnionych sytuacjach, gdy istnieje ryzyko, że zwyczajowa dieta nie dostarcza witamin i składników mineralnych w ilości odpowiedniej do pokrycia zapotrzebowania organizmu. Należy jednak pamiętać o realnym niebezpieczeństwie wynikającym z przyjmowania zbyt dużych dawek witamin i składników mineralnych. U wielu osób stosujących suplementy diety, zwłaszcza kilka rodzajów jednocześnie, mogą wystąpić niepożądane skutki uboczne i pogorszenie stanu zdrowia, a u osób przyjmujących leki - może dodatkowo dojść do poważnego zakłócenia lub osłabienia działania leku, a nawet braku efektu leczniczego. W dokumencie przedstawiono 10 kroków i zasad korzystania z dostępnych na rynku suplementów diety, które skierowano do populacji generalnej.

Słowa kluczowe: dieta, skladniki mineralne, witaminy, suplementy, niedobory, żywienie, żywność, osoby doroste

* This Statement is also published in Polish language on the journal's website and in the Stand Med Pediatr 2021;18:299-304

Corresponding author: Agata Wawrzyniak, Katedra Żywienia Człowieka, Szkoła Główna Gospodarstwa Wiejskiego, ul. Nowoursynowska 159C, 02-776 Warszawa, e-mail: agata_wawrzyniak@sggw.edu.pl

(C) Copyright by the National Institute of Public Health NIH - National Research Institute 
The use of dietary supplements (supplementation) is the individual enrichment of the diet with ingredients naturally occurring in food. As a rule, dietary supplements should be taken periodically [1]. In nutritional practice, there are many indications for supplementation, but the decision to take dietary supplements should be made by consumers wisely and only in justified situations, when there is a risk that a regular diet will not provide vitamins and minerals in an amount adequate to comply with dietary recommendations. Dietary supplements that have been introduced to the Polish market are safe and should not pose a threat to the health and life of consumers, but their improper use may pose a threat. Taking dietary supplements should be consulted with doctor, nutritionist or pharmacist as there is a risk of overdosing or interactions with food, medicines or other supplements. Eating a varied diet based on available food should always be considered as the first step in improving the nutritional status and health.

\section{LEGAL REGULATIONS AND DIETARY SUPPLEMENTS}

The Act of Food Safety and Nutrition of 25 August 2006 [10], defines a dietary supplement as a food, supplementing a normal diet, being a concentrated source of vitamins or minerals or other substances with a nutritional or other physiological effect, single or complex, marketed in dosage form, in the form of: capsules, tablets, dragees and other similar forms, powder sachets, liquid ampoules, dropper bottles and other similar forms of liquids and powders intended for consumption in small, measured unit amounts, excluding products with the properties of a medicinal product within the meaning of pharmaceutical law.

The above conditions should be met cumulatively.

The ingredients of dietary supplements can be:

- vitamins: $\mathrm{A}, \mathrm{D}, \mathrm{E}, \mathrm{K}, \mathrm{B}$ vitamins $\left(\mathrm{B}_{1}, \mathrm{~B}_{2}, \mathrm{~B}_{6}, \mathrm{~B}_{12}\right.$, niacin, pantothenic acid, folic acid, biotin), vitamin $\mathrm{C}$;

- minerals: calcium, phosphorus, magnesium, iron, zinc, copper, iodine, selenium, fluorine, manganese, sodium, potassium, chlorine (chlorides) and others, e.g. boron, chromium, silicon, molybdenum;

- other substances, e.g. amino acids, fatty acids, dietary fiber, pro and prebiotics, substances of plant origin and others having a potential biological effect on the body.

Dietary supplements are labeled with the following information on the packaging:

- the term "dietary supplement";
- the name of the category of nutrients or substances characterizing the product or an indication of their properties;

- the portion of the product recommended for consumption during the day;

- a warning about not exceeding the recommended daily dose;

- a statement that dietary supplements cannot be used as a substitute (replacement) for a varied diet;

- a statement that dietary supplements should be stored out of reach of small children;

- information on the content of vitamins and minerals;

- the content of vitamins and minerals as a percentage of the recommended daily intake.

The labeling of dietary supplements must not attribute to them the property of preventing, treating, or cure human diseases or suggest such properties. This policy also applies to advertising.

\section{DIETARY SUPPLEMENTS AND MEDICINES}

A medical claim that states, suggests, or implies that a product or ingredient(s) has properties for treating or preventing disease(s) are proprietary to medicaments.

Dietary supplements, like medicines and medical devices, are in the form of tablets, dragees, capsules, drops, powders, but the differences between these products are fundamental (Table 1). This applies not only to the method of operation, but also to the principles of marketing authorization, intended use, and the possibility of advertising the preparation and placing it on the market. A drug differs from a medical device, among other, mode of action. Medicinal products (medicines) have a pharmacological effect, i.e. they cure or prevent a disease, and medical devices only have a physical and mechanical effect. Thus, the effect of the medical devices is limited compared to the medicines. Diet supplements, on the other hand, are used to enrich the usual diet (based on typically consumed food). They do not have any healing properties, but they can support the functioning of the body, improving its nutritional status.

In the light of legal regulations [2, 3, 5, 7, 8, 9], the maximum content of vitamins and minerals in a daily portion of a dietary supplement should be determined taking into account:

- the upper level of safe intakes (UL) for vitamins and minerals based on scientific risk assessment and generally accepted scientific data, taking into account the varying degrees of sensitivity of different groups of consumers; 
able 1 . The main differences between food supplements and medicines

\begin{tabular}{|c|l|l|}
\hline Differences & \multicolumn{1}{|c|}{ Food supplement } & \multicolumn{1}{|c|}{ Medicines } \\
\hline Intended use & $\begin{array}{l}\text { A food supplement is used to supplement } \\
\text { the nutritional value of a regular diet. It is } \\
\text { intended for healthy individuals who do not have } \\
\text { an adequate supply of certain ingredients in their } \\
\text { diet. }\end{array}$ & $\begin{array}{l}\text { A medicine is used to treat or prevent } \\
\text { diseases. It is intended for people who are ill or } \\
\text { at increased risk of developing the disease. }\end{array}$ \\
\hline Safety & $\begin{array}{l}\text { Food supplements satisfy the requirements } \\
\text { applying to foodstuffs. The content of an } \\
\text { ingredient in the product may differ from the } \\
\text { amount declared on the label by -20\% to +50\% } \\
\text { for vitamins and -20\% to +45\% for minerals. }\end{array}$ & $\begin{array}{l}\text { Each medicine is subject to detailed testing } \\
\text { of its composition. Only small, strictly defined } \\
\text { differences in the content of a given component } \\
\text { resulting from the test method used are } \\
\text { permitted. }\end{array}$ \\
\hline $\begin{array}{c}\text { Placing on } \\
\text { the market in } \\
\text { Poland }\end{array}$ & $\begin{array}{l}\text { A food supplement is a food item and therefore } \\
\text { does not require a marketing authorisation. } \\
\text { The decision to market it is taken by the } \\
\text { entrepreneur, who notifies the Chief Sanitary } \\
\text { Inspector (GIS). In case of any doubt, the } \\
\text { Chief Sanitary Inspector may initiate a } \\
\text { clarification procedure. }\end{array}$ & $\begin{array}{l}\text { A medicine, before it can be marketed, must } \\
\text { be approved by the Office for Registration } \\
\text { of Medicinal Products, Medical Devices and } \\
\text { Biocidal Products (URPL, WMiPB). The } \\
\text { product label shows the marketing authorisation } \\
\text { number of the medicines. }\end{array}$ \\
\hline $\begin{array}{c}\text { Inclusion in a } \\
\text { relevant list }\end{array}$ & $\begin{array}{l}\text { Products that have been approved as food } \\
\text { supplements are listed in the special Register of } \\
\text { Products www.rejestrzp.gis.gov.pl }\end{array}$ & $\begin{array}{l}\text { Medicines that have been authorised for } \\
\text { marketing in Poland are included in the Official } \\
\text { List of Medicinal Products www.urpl.gov.pl }\end{array}$ \\
\hline
\end{tabular}

Source: https://gis.gov.pl/wp-content/uploads/2020/01/suplementy-diety_A5.pdf

- intake of vitamins and minerals from food and drinking water, including fortified foods;

- recommended intakes of vitamins and minerals for the population, taking into account different groups of consumers.

In Poland, the Team for Diet Supplements, which functions within the Sanitary and Epidemiological Council, as an advisory body to the Chief Sanitary Inspector (GIS), has been entrusted with determining the maximum content of vitamins and minerals in dietary supplements. The Team for Diet Supplements develops opinions in the form of resolutions on the maximum daily amounts of vitamins and minerals in dietary supplements (in the recommended daily dose) intended for adults, with additional guidelines (Table 2).

Additional guidelines of the Team for Diet Supplements regarding the maximum content of vitamins and minerals in dietary supplements [4]:

- vitamin D - before use, it is advisable to test the concentration of $25(\mathrm{OH}) \mathrm{D}$ in the blood and consult the result of the test with a doctor or pharmacist;

- vitamin C - in the labeling of dietary supplements with a high content of vitamin $\mathrm{C}$, it is recommended to include a warning: "Do not use in people with a predisposition to the formation of kidney stones or suffering from kidney stones";

- vitamin A - $800 \mu \mathrm{g}$ in the form of retinol equivalent (retinol and retinyl esters) and $7 \mathrm{mg}$ in the form of $\boldsymbol{\beta}$-carotene;

- folic acid - $800 \mu \mathrm{g}$ if the supplement is marked as intended for pregnant women; in addition, it is recommended to include a warning: "In pregnant women, use after consulting a doctor";

- niacin - $830 \mathrm{mg}$ in the form of nicotinic acid amide or $16 \mathrm{mg}$ in the form of nicotinic acid;

- pantothenic acid - $10 \mathrm{mg}$ in the form of pantethine or $200 \mathrm{mg}$ in the other chemical forms, expressed as pantothenic acid;

- iodine - $200 \mu \mathrm{g}$ if the supplement is designated as intended for pregnant and lactating women;

- iron - $30 \mathrm{mg}$ if the supplement is marked as intended for pregnant women; in addition, it is recommended to include a warning: "Supplement for pregnant women, use after consulting a doctor";

- vitamin K - in the labeling of dietary supplements with a high content of vitamin $\mathrm{K}$, it is recommended to include a warning: "The supplement should not be consumed by people taking anticoagulants containing vitamin $\mathrm{K}$ antagonists (eg. warfarin and acenocoumarol)";

- boron - $3 \mathrm{mg}$;

- chromium - $200 \mu \mathrm{g}$.

\section{THE INTAKE OF FOOD SUPPLEMENTS AND CONSUMER SAFETY}

The use of food supplements containing vitamins and minerals may, for some people, improve compliance with dietary recommendations and more fully meet the body's requirements for these nutrients. However, it should be remembered that taking excessive doses of vitamins and minerals involves a real risk (Table 2 and 3). For many individuals, 
taking food supplements, especially several types of supplements at the same time, undesirable side effects and deterioration of health may occur and, in those taking medicines, the effect of their medicines may additionally be seriously affected or impaired or the therapeutic effect may even be completely absent. For these reasons, food supplements need to be appropriately labelled by the manufacturer, i.e. to include reliable information on contraindications to the use of these preparations, to indicate possible interactions with medicines, food components or components of other food supplements and to recommend that consumers consult their doctor before using them, especially if they are ill or taking medicines.

\section{TEN STEPS AND RULES FOR USING FOOD SUPPLEMENTS}

Based on current scientific knowledge and existing legislation, ten steps and rules have been formulated for using food supplements available on the market:

1. Ongoing education of the public concerning the principles of proper nutrition and a well-balanced diet through the consumption of a wide variety of foods.

2. Before using a food supplement, a qualitative and quantitative assessment of the diet should be conducted by a dietician or another professional, taking into account the individual needs of the consumer according to gender, age, physical activity and physiological state (pregnancy, breastfeeding).

Table 2. Recommended daily allowances (RDA) of vitamins and minerals in Poland in relation to the upper safe level of intake (UL) from food, drinking water and food supplements jointly, as well as their maximum daily amounts in food supplements (according to the values provided by the Team for Diet Supplements) [4]

\begin{tabular}{|c|c|c|c|}
\hline Component & RDA for an adult & UL values for an adult & $\begin{array}{l}\text { Maximum daily amount } \\
\text { in the recommended daily } \\
\text { portion of the supplement }\end{array}$ \\
\hline Vitamin A $(\mu \mathrm{g})$ & $700^{1 / /} 900^{2)}$ & 3000 & 800 \\
\hline Vitamin D $(\mu \mathrm{g})$ & 15 (600 IU) & 100 (4000 IU) & $\begin{array}{l}50(2000 \mathrm{IU})^{6 /} / \\
100(4000 \mathrm{IU})^{7)}\end{array}$ \\
\hline Vitamin E (mg) & $8^{1) /} / 10^{2)}$ & 300 & 250 \\
\hline Vitamin $\mathrm{K}(\mu \mathrm{g})$ & $55^{1)} / 65^{2)}$ & no data & 200 \\
\hline Vitamin C (mg) & $75^{1 / /} 90^{2)}$ & no data & 1000 \\
\hline Thiamine (mg) & $1.1^{1)} / 1.3^{2)}$ & no data & 100 \\
\hline Riboflavin (mg) & $1.1^{1)} / 1.3^{2)}$ & no data & 40 \\
\hline Niacin (mg) & $14^{1) /} 16^{2)}$ & $\begin{array}{l}\text { nicotinic acid }-10 \mathrm{mg} \\
\text { nicotinamide }-900 \mathrm{mg}\end{array}$ & 16 \\
\hline Vitamin $B_{6}(\mathrm{mg})$ & $1.5^{1)} / 1.7^{2)}$ & 25 & 18 \\
\hline Folacin $(\mu \mathrm{g})$ & 400 & 1000 as folic acid & 600 as folic acid \\
\hline Vitamin $B_{12}(\mu \mathrm{g})$ & 2.4 & no data & 100 \\
\hline Biotin $(\mu \mathrm{g})$ & 30 & no data & not established \\
\hline Pantothenic acid (mg) & 5 & no data & 10 \\
\hline Calcium (mg) & $1000^{3 /} / 1200^{4)}$ & 2500 & not established \\
\hline Phosphorus (mg) & 700 & no data & 450 \\
\hline Magnesium (mg) & $320^{1) /} 420^{2)}$ & $250^{5)}$ & 400 \\
\hline Iron (mg) & $18^{1) / 10^{2)}}$ & no data & 20 \\
\hline Zinc (mg) & $8^{1) / 11^{2)}}$ & 25 & 15 \\
\hline Copper (mg) & 0.9 & 5 & 2 \\
\hline Iodine $(\mu \mathrm{g})$ & 150 & 600 & 150 \\
\hline Selenium $(\mu \mathrm{g})$ & 55 & 300 & not established \\
\hline Fluoride (mg) & $3^{1) /} 4^{2)}$ & 7 & 3.5 \\
\hline Manganese (mg) & $1.8^{1 /} / 2.3^{2)}$ & no data & 1.8 \\
\hline
\end{tabular}

${ }^{1)}$ women; ${ }^{2)}$ men; ${ }^{3)}$ for women under 50 and men under $65 ;{ }^{4)}$ for women 50 or over, and men 65 or over; ${ }^{5}$ value for the intake of magnesium from food supplements and magnesium added to food (excluding magnesium naturally occurring in products); ${ }^{6}$ for the healthy adult population under $75 ;{ }^{7)}$ for the healthy adult population 75 or over 
Table 3. The presence of risks related to excessive intake of vitamins or minerals with food supplements in adults [6]

\begin{tabular}{|c|l|l|}
\hline Group & Health risk & Component \\
\hline A & $\begin{array}{l}\text { No evidence of risk to human health at current } \\
\text { levels of consumption } \\
\text { (from all sources in total) }\end{array}$ & $\begin{array}{l}\text { thiamine (vitamin } \mathrm{B}_{1} \text { ), riboflavin (vitamin } \mathrm{B}_{2} \text { ), } \\
\text { biotin, vitamin } \mathrm{B}_{12}, \text { pantothenic acid, vitamin } \mathrm{K}, \\
\text { chromium (III) }\end{array}$ \\
\hline $\mathrm{B}$ & The risk of exceeding $\mathrm{UL}^{*}$ is low & $\begin{array}{l}\text { vitamins: } \mathrm{B}_{6}, \mathrm{C}, \mathrm{D}, \mathrm{E}, \text { folic acid, nicotinamide, } \\
\text { phosphorus, magnesium, molybdenum, selenium, } \\
\text { potassium }\end{array}$ \\
\hline $\mathrm{C}$ & $\begin{array}{l}\text { There is a risk of excessive intake when using } \\
\text { supplements }\end{array}$ & $\begin{array}{l}\text { vitamin A, beta-carotene, calcium, copper, iodine, } \\
\text { iron, manganese, zinc }\end{array}$ \\
\hline
\end{tabular}

${ }^{*}$ UL (Upper Level) - upper safe level of the component intake with food, drinking water and food supplements

3. If a diet is found to be poorly balanced in relation to the dietary recommendations, making changes to food intake and ensuring the consumption of food enriched with vitamins and minerals.

4. Carrying out medical and biochemical tests on nutritional status to assess health condition and confirm vitamin and mineral deficiencies in the body.

5. Choosing an appropriate food supplement, while eliminating the risk of potential interactions associated with the simultaneous intake of several food supplements or interactions between a food supplement and medicines.

6. Using food supplements only from verified sources.

7. Educating patients on the use of the food supplement to minimize the risk of adverse reactions resulting from excessive intake, i.e. exceeding the upper safe intake level (UL) for vitamins and minerals (including diet, drinking water and food supplements).

8. Seeking follow-up advice from a doctor and a dietician to monitor the effectiveness of the food supplement and, if necessary, to change the type or dose of the food supplement.

9. After periodic dietary supplementation and confirming the elimination of vitamin and mineral deficiencies in the body, discontinuing the intake of the food supplement and following a well-balanced diet.

10. For population groups at higher risk of deficiencies, e.g. children, adolescents, the elderly and pregnant [11] or lactating women, following the recommendations addressed to those groups by the relevant expert panels and, in the case of sick persons, following individual medical advice.

\section{REFERENCES}

1. Brzozowska A., Roszkowski W., Pietruszka B., Katuża $J .:$ Witaminy i składniki mineralne jako suplementy diety [Vitamins and minerals as dietary supplements]. Żywność Nauka Technologia Jakość 2005;4(Supl.):5-16 (in Polish).
2. Discussion Paper on the setting of maximum and minimum amounts for vitamins and minerals in foodstuffs, European Commission, 2006. Available https://ec.europa.eu/food/sites/food/files/safety/docs/ labelling_nutrition-supplements-discus_paper amount_vitamins_en.pdf(Accessed 17.05.2021).

3. Dyrektywa 2002/46/WE Parlamentu Europejskiego i Rady z dnia 10 czerwca 2002 r. w sprawie zbliżenia ustawodawstwa państw członkowskich odnoszącego się do suplementów diety [Directive 2002/46/EC of the European Parliament and of the Council of 10 June 2002 on the approximation of the laws of the Member States relating to food supplements], Dz. U. L 183 z 12.7.2002, 51-57 z późn. zm. (in Polish) [Official Journal of the European Communities L 183, 12.7.2002].

4. Jarosz M., Rychlik E., Stoś K., Charzewska J. eds. Normy żywienia dla populacji Polski i ich zastosowanie [Nutrition recommendations for the Polish population and their application]. Warsaw, NIZP-PZH 2020 (in Polish). Available https://www.pzh.gov.pl/wp-content/ uploads/2020/12/Normy_zywienia_2020web-1.pdf (Accessed 17.05.2021).

5. Overview on Tolerable Upper Intake Levels as derived by the Scientific Committee on Food (SCF) and the EFSA Panel on Dietetic Products, Nutrition and Allergies (NDA), Summary of Tolerable Upper Intake Levels, September 2018. Available https://www.efsa. europa.eu/sites/default/files/assets/UL_Summary tables.pdf (Accessed 17.05.2021).

6. Richardson D.P.: Risk management approaches to the setting of maximum levels of vitamins and minerals in food supplements for adults and for children aged 4-10 years. Food Supplements Europe, July 2014. Available https://foodsupplementseurope.org/wp-content/themes/ fse-theme/documents/publications-and-guidelines/ fseriskmanagement.pdf. (Accessed 17.05.2021).

7. Rozporządzenie Ministra Zdrowia z dnia 9 października 2007 r. w sprawie składu oraz oznakowania suplementów diety [Regulation of the Polish Minister of Health of 9 October 2007 on the composition and labeling of dietary supplements], Dz. U. 2007, 196, 1425, z późn. zm. (in Polish).

8. Stoś K., Głowala A., Ziółkowska I.: Normy a suplementacja [Nutrition recommendations and supplementation]. In: Jarosz M., Rychlik E., Stoś K., Charzewska J. (eds.) Normy żywienia dla populacji Polski i ich zastosowanie [Nutrition recommendations 
for the Polish population and their application]. Warsaw, NIZP-PZH 2020;414-424 (in Polish).

9. Suplementy witamin i składników mineralnych: model zarządzania ryzykiem [Vitamin and mineral supplements: a risk management model] (translation: Stoś K. Żyw Człow Metab 2005;32:5-29).

10. Ustawa $z$ dnia 25 sierpnia 2006 r. o bezpieczeństwie żywności i żywienia [The Act of Food Safety and Nutrition of 25 August 2006]. Dz.U. 2006, no 171 item 1225, amendments 2020.2021 (in Polish). Available https://sip.lex.pl/akty-prawne/dzu-dziennik-ustaw/ bezpieczenstwo-zywnosci-i-zywienia-17302608 (Accessed 17.05.2021).

11. Zimmer M., Sieroszewski P., Oszukowski P., Huras H., Fuchs T., Pawlosek A.: Polish Society of Gynecologists and Obstetricians recommendations on supplementation during pregnancy. Ginekol Pol 2020;91:644-653 doi: 10.5603/GP.2020.0159.

Received: 18.06.2021

Accepted: 05.07.2021

Published online first: 23.07.2021 